\title{
Competence and Work Environment Influences on Employees' Motivation and Performance at Regional Financial and Asset Management Agency of the Regency of Karangasem
}

\author{
Ni Made Wahyuni ${ }^{1}$, I Nengah Adhi Suteja ${ }^{2}$, Ni Wayan Sitiari ${ }^{3}$ \\ Magister of Management, Postgraduate Program, Universitas Warmadewa, Denpasar, \\ Indonesia ${ }^{1,2,3}$ \\ \{info@warmadewa.ac.id $\left.{ }^{1}\right\}$
}

\begin{abstract}
Employee performance in regional apparatus organizations refers to employee work performance or work appraisal or what is referred to as Employee Work Target (SKP) which consists of work contracts, measurement and assessment of work performance measured based on the achievement of activities in accordance with job descriptions in a given period. This examines the influence of work environment and employee competence on their motivation and performance at the Regional Financial and Asset Management Agency (BPKAD) of the Regency of Karangasem. The existing condition was that the employees of the agency lacked maximum performance. To achieve the objective of the present research, an explanatory type of research was adopted in the conducting the present research. 86 civil servants of the BPKAD were the samples taken for the study. Data were collected using onbservation, interviews, and questionnaires. The data were analysed using PLS (Partial Least Square). The results showed that both employee competence and and work environment had a positive and significant influence on the employee motivation and work environment and motivation had a positive and significant influence on the employee performance. It was motivation serving as the perfect mediation of the influences of competence on performance, whereas it was motivation serving as the partial mediation between the influences of work environment on the employee performance.
\end{abstract}

Keywords: Competence; Work Environment; Motivation; Peformance

\section{Introduction}

In government organizations or what are called regional instruments, human resources play a role in achieving work plans that have been made and compiled in the form of programs and activities, in this case having an important role in carrying out public services. Human resources referred to here are Civil Servants $(A S N-P N S)$ who work in local government agencies. Regional Finance and Asset Management Agency (BPKAD) of Karangasem Regency is one of the regional instruments which is coordinative in nature which has the main 
task in formulating technical policies and public services in the area of regional finance and asset management. A 2017 activity report shows less than optimal results, including physical realization that there are still program targets and activities that have not been achieved according to plan, this shows that there are poor performance that should be targeted by programs and activities as planned. While the financial realization shows that there is still a large remaining budget (SiLPA) at the end of the fiscal year, this shows an inaccurate budget plan in calculating the estimated budget requirements in supporting programs and activities.

Employee performance is absolutely necessary because through it the extent to which the employee's prowess in carrying out the tasks assigned to him can be measured. Employee performance represents the combination of skills, business, and opportunities that can be assessed from their endeavor (Riyanto, Sutrisno, \& Ali, 2017). Employee performance or work performance refers to the results of work in terms of the quality and quantity achieved by an employee from performing their duties according to the responsibilities assigned to them (Waris, 2015).

Factors that can influence human resources in carrying out their duties and responsibilities come not only from outside themselves, but also from within. The factors in individuals that can influence employee performance are competence and motivation. While the external factors that can affect performance are the work environment (Wibowo, 2017).

Competence depicts the behavioral characteristics that underlie the motives, personal characteristics (characteristics), self-concept, values, knowledge or skills carried by the superior performing workplace (Mukhtar, 2018). Competence is related to cognitive fitness for certain types of tasks, systems of individual abilities, skills, or inclinations to learn and do things successfully and to achieve specific goals (Abas \& Imam, 2016). Mulyanto, Awatara, \& Gunardi (2018) put the notion of competence as an individual's fundamental characteristic that is causally interconnected with a criterion called effective performance and / or superiority in a job or situation.

Motivation is the strength in a person that characterizes the determination and effort of individuals to achieve the organizational goals and to support the growth of the organization at which they work (Butt, Hu, Shafi, \& Malik, 2015). Motivation is always associated with the activities a person does in relation to their urge or it refers to the attitude to do something, the attraction of the external environment causes someone to take or not to take actions (Roni, Moein, \& Effendi, 2018). In the context of organization, the concept of motivation is associated with work and behavior that channel employees' efforts to achieve organizational goals (Hee, Kamaludin, \& Ping, 2016).

Work environment refers to the relationship between people within a workplace and the equipment the people make use of, which gives benefits in both short and long-term performance, health and safety (Roni et al., 2018). In addition, work environment refers to everything outside the company that has an influence on the growth, development and progress of the company (Riyanto et al., 2017).

A study conducted by Farida (2014) examined the influence of competence and work environment on motivation and on the performance of civil servants at the Inspectorate of Bungo District. The research revealed that employee motivation and performance were positively and significantly influenced by competence and work environment. In addition, performance was also positively and significantly influenced by motivation as a mediating variable. Another study examined the effect of employee competence and work environment on employee performance through their performance as an intervening variable. In the research results, it was found that employee performance was not directly influenced by employee competence and work environment, but after the intervening variable work 
motivation was tested the effects were seen (Basori, Prahiawan, \& Daenulhay, 2017). Grounded by the elucidation put above, the present study examines the influences of employees' competence and work environment on employees' motivation and perfomance at the regional finance and asset management of the Regency of Karangasem.

\section{Concept and Hypotheses}

Based on the formulation of the problem that has been explained, the factors that are thought to be quite dominant influence the performance of employees are competency, work environment, and motivation which subsequently compiled a conceptual framework. The conceptual framework in this study is presented in Figure 1 as follows:

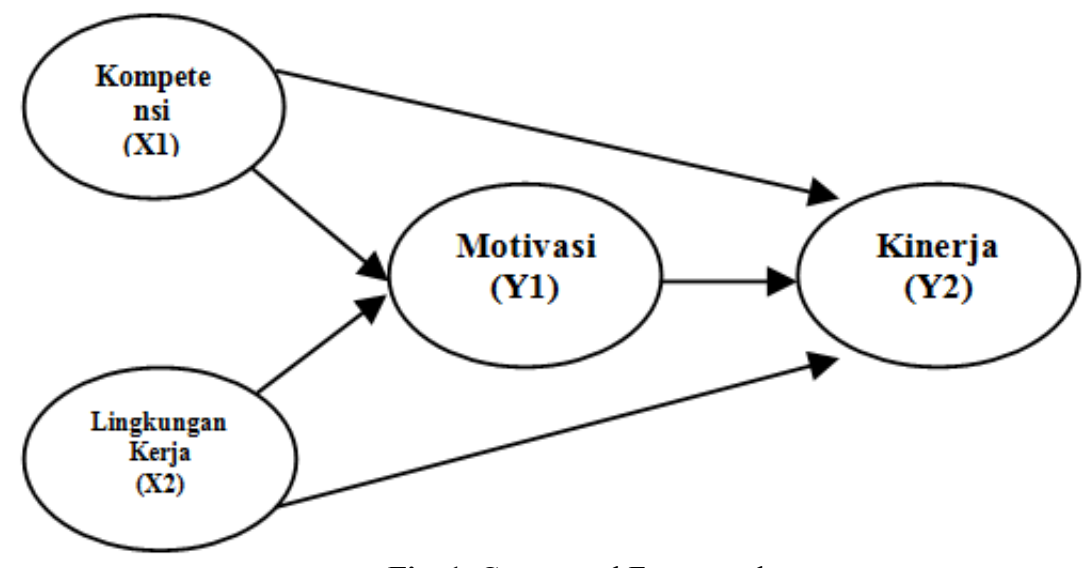

Fig. 1. Conceptual Framework

In line with the statements put above, hypotheses of the study are formulated as follows:

H1 : Competence has a positive and significant effect on motivation.

H2 : Work environment has a positive and significant effect on motivation.

H3 : Competence has a positive and significant effect on employee performance.

H4 : Work environment has a positive and significant effect on employee performance.

H5 : Motivation has a positive and significant effect on employee performance.

H6 : Motivation mediates the influence of competence on employee performance.

H7 : Motivation mediates the influence of the work environment on employee performance.

\section{Method}

The type of research used in this study is explanatory research. It was conducted at the Regional Finance and Asset Management Agency (BPKAD) of the regency of Karangasem. The total samples of the research participants was 86 people selected from 109 civil servants of the agency in population. The data of the research were collected from the selected samples using observation, interviews, and questionnaires. The data were analysed using PLS (Partial Least Square). The study involves two independent variables, competence $\left(\mathrm{X}_{1}\right)$ and work environment $\left(\mathrm{X}_{2}\right)$, an intervening variable which is motivation (Y1), and two dependent variables which are motivation (Y1) and performance (Y2). 


\section{Result And Discussion}

\subsection{Effect of Competence on Motivation}

As shown in the results of testing the influence of competence on motivation, it obtained that motivation is pisitively and significantly influenced by the competence. This implies that the higher the competence held by an employee, the more their motivation will increase. The increase in competence, especially the knowledge of operating computers can increase motivation to work. Having high competencies tends to also have high motivation in carrying out tasks to achieve organizational goals. The results of this study are also supported by some studies which states that motivation is positively and significantly influenced by competence (Ngantemin \& Arumwanti, 2012), (Sudarwati, 2014), (Sumantri, 2017), (Suyanto, 2018), (Roni et al., 2018).

\subsection{The Influence of Work Environment on Motivation}

As indicated by the results of the test of the influence of work environment toward motivation, it is obtained that the positively influence the motivation and the relationship between the two is significant. It means that the more conducive the environment of work in an organisation, the more motivated the employees will be. By existing a good work environment such as physical and non-physical environment greatly affects the encouragement and enthusiasm in carrying out their work. A comfortable and safe atmosphere and the harmony of individual relationships in work can increase employee motivation in working to achieve organizational goals. This fact is connected with the findings of a study which reveals that motivation is positively and significantly influenced by work environment (Roni et al., 2018), (Prakoso, 2014), (Rezita, Pendidikan, \& Perkantoran, 2014), (Warouw, Sumayku, \& dan Tumbel, 2017), (Sutanto \& Ratna, 2013).

\subsection{Effect of Competence on Employee Performance}

As exposed in the results of testing of the influence of competence on performance, it is obtained that there is no positive influence of the variable on performance and the relationship is insignificant. The negative relationship indicates that the higher the level of competency of employees, but it turns out the performance of employees decreases. Relations that do not significantly indicate that the increase or decrease in competence is does not have a trong influence on an employee's performance improvement.

The facts in the field indicate that the placement of employees who are not in accordance with their competencies has an effect on employee performance. Besides that, increasing competence through training and technical guidance as well as the task of learning civil servants is done solely to support the career of civil servants and to fill certain positions. Other facts show that employees in carrying out their duties prioritize experience, coordination and communication between work units and other regional device organizations. This is because basically BPKAD Karangasem Regency is a coordinative agency, which means that the characteristics and nature of work in regional financial management prioritize coordination and communication with various stakeholders. In most part, the finding of the study at this part is not in line with that of the preceeding studies finding that employees' performance can be in improved by competence (Muhammad Arifin, 2015), (Waris, 2015), (Sajid, 2019). 


\subsection{Effect of Work Environment on Employee Performance}

The results of the testing of the influence of work environment on employee performance indicate that the employees' performance is positively influenced by the work environment and the relationship is significant. It implies that the better the work environment in an organisation, the more the employees' performance will increase. Such a result is supported by that of some of previously conducted studies (Nguyen, Dang, \& Nguyen, 2015), (Riyanto et al., 2017) and (Anggreni, Sitiari, Luh, Indiani, \& Pertamawati, 2018). A comfortable and safe work environment and harmonious relationships between employees are absolutely necessary for every organization, both public and private organizations. A conducive work environment will have a positive impact on employees' performance improvement.

\subsection{The Influence of Motivation on Employee Performance}

The results of testing the influence of motivation on employee performance indicate that performance is positively influenced by motivation and the relationship between the two is significant. This finding implies that if an employee's motivation is higher, their performance will increase significantly.With high work motivation, a person's enthusiasm and passion to be able to work together effectively and integrated with all existing components and all their efforts to achieve organisational goals will be formed. These finding confirms the findings of several studies showing that employee performance is positively and significantly affected by motivation (Azar \& Shafighi, 2013), (Dar, 2014), (Usman, Sukmayuda, \& Kurniawati, 2019) (Hee et al., 2016), (Hidayah \& Tobing, 2018).

\subsection{Role of Motivation in Mediating the Effect of Competence on Employee Performance}

The test results show that motivation is perfect mediation (complete mediation) between the influences of competence on performance, because the relationship of competence to motivation is significant and the relationship of motivation to performance is significant, while the relationship between competence and performance is not significant. This means that motivation is a way to improve employee performance at the BPKAD Karangasem Regency. By having competence in carrying out tasks, it will have an effect on increasing employee work motivation and with high work motivation will have an effect on improving employee performance. The results of this study supported by the study which stated that motivation mediates the influence of competencies on employee performance (Rinawati \& Ingsih, 2014).

\subsection{Role of Motivation in Mediating the Effects of the Work Environment on Employee Performance}

Based on the test results show that motivation is a partial mediation between the influence of the work environment on performance, because the direct relationship of the work environment to the performance coefficient is greater than the relationship of the work environment to performance through motivation, while the entire relationship shows both direct and indirect relationships.

Motivation plays an important role in improving employee performance. Someone who has high motivation will be able to work well without supervision from others. However in this study the work environment plays a role that is more in improving employee performance 
compared to motivation. This is consistent with the statement that in order to achieve high employee performance, it is necessary to support a good work environment (Anggreni et al., 2018).

\section{Conclusions}

Based on the results and discussion of the research, it can be concluded that some things have a positive and significant influence on employee motivation on BPKAD Karangasem Regency, the work environment has a positive and significant influence on employee motivation on the BPKAD in Karangasem Regency. Competence has a negative and not significant effect on employee performance. This gives the meaning that the higher the level of competency but it turns out the employee's performance decreases. Relations that do not significantly indicate that the increase or decrease in competence has a weak influence on improving employee performance in the BPKAD Karangasem Regency.

The work environment has a positive and significant influence on the performance of employees at the BPKAD Karangasem Regency. These results mean that the better and more comfortable the work environment perceived by employees, the more significant the performance of the Karangasem Regency BPKAD employees will be. Motivation has a positive and significant influence on the performance of employees in the BPKAD Karangasem Regency. This result gives the meaning that the higher the motivation of employees, the more it will significantly improve the performance of the staff of BPKAD in Karangasem Regency.

Motivation mediates perfectly (complete mediation) the influence of competence on employee performance. This gives the meaning that good competence will affect the increase in employee motivation and with high employee motivation will affect the improvement of employee performance. Motivation partially mediates the influence of the work environment on employee performance. This gives the meaning that with high motivation will be able to improve employee performance, but the influence of the work environment is better in improving employee performance than motivation.

\section{References}

[1] Abas, M. C., \& Imam, O. A. (2016). Graduates' Competence on Employability Skills and Job Performance. International Journal of Evaluation and Research in Education (IJERE), 5(2), 119. https://doi.org/10.11591/ijere.v5i2.4530

[2] Anggreni, N. W., Sitiari, N. W., Luh, N., Indiani, P., \& Pertamawati, N. P. (2018). The Effect of Leadership and Work Environment on Employee Performance Through Mediation of Work Spirit at Prama Sanur Beach Hotel. Jurnal Ekonomi Dan Bisnis Jagaditha, 5(2), 84-91.

[3] Azar, M., \& Shafighi, A. A. (2013). The Effect of Work Motivation on Employees' Job Performance (Case Study: Employees of Isfahan Islamic Revolution Housing Foundation). International Journal of Academic Research in Business and Social Sciences, 3(9), 432-445. https://doi.org/10.6007/ijarbss/v3-i9/231

[4] Basori, M., Prahiawan, W., \& Daenulhay. (2017). Pengaruh Kompetensi Karyawan dan Lingkungan Kerja terhadap Kinerja Karyawan melalui Motivasi Kerja sebagai Variabel Intervening (Studi pada PT. Krakatau Bandar Samudera). Jurnal Riset Bisnis dan 
Manajemen Tirtayasa, 1(2).

[5] BUTT, M., HU, P., SHAFI, K., \& MALIK, B. H. (2015). Study of Organizational Environment, Incentives and Promotion and its Effect on Employee's Motivation. International Journal of Academic Research in Accounting, Finance and Management Sciences, 5(3). https://doi.org/10.6007/ijarafms/v5-i3/1801

[6] Dar, A. T. (2014). Mediating Role of Employee Motivation in Relationship to PostSelection HRM Practices and Organizational Performance. International Review of Management and Marketing, 4(3), 224-238.

[7] Farida. (2014). Pengaruh Kompetensi dan Lingkungan Kerja terhadap Motivasi serta Dampaknya terhadap Kinerja Pegawai Negeri Sipil pada Inspektorat Kabupaten Bungo. Masters thesis, Universitas Terbuka.

[8] Hee, O. C., Kamaludin, N., \& Ping, L. (2016). Motivation and job performance among nurses in the health tourism hospital in Malaysia. International Review of Management and Marketing, 6(4), 668-672.

[9] Hidayah, T., \& Tobing, D. S. K. (2018). The influence of job satisfaction, motivation, and organizational commitment to employee performance. International Journal of Scientific and Technology Research, 7(7), 122-127.

[10] Muhammad Arifin, H. (2015). The influence of competence, motivation, and organisational culture to high school teacher job satisfaction and performance. International Education Studies, 8(1), 38-45. https://doi.org/10.5539/ies.v8n1p38

[11] Mukhtar, A. (2018). The effect of competence and organization culture to work satisfaction and employee performance of Sharia banks in Makassar city. International Journal of Scientific and Technology Research, 7(10), 1-6.

[12] Mulyanto, Awatara, I. G. P. D., \& Gunardi, A. (2018). Enhancing Competence, Environmental Management System, Job Satisfaction and Employee Performance. Journal of Environmental Management and Tourism, IX(1 (25).

[13] Ngantemin, \& Arumwanti, W. (2012). Vol. 12 No. 2. Jurnal Riset Akuntansi Dan Bisnis, 12(2).

[14] Nguyen, P., Dang, C., \& Nguyen, D. D. L. (2015). Would Better Earning, Work Environment, and Promotion Opportunities Increase Employee Performance? An Investigation in State and Other Sectors in Vietnam. Public Organization Review, 15, 565-579. https://doi.org/10.1007/s11115-014-0289-4

[15] Prakoso, R. (2014). Pengaruh Lingkungan Kerja Terhadap Motivasi Kerja dan Kinerja Karyawan (Studi Pada Karyawan PT. AXA Financial Indonesia Cabang Malang). Jurnal Administrasi Bisnis S1 Universitas Brawijaya, 14(2), 1-10.

[16] Rezita, R., Pendidikan, P., \& Perkantoran, A. (2014). Pengaruh Lingkungan Kerja Terhadap Motivasi Kerja Karyawan di Bank Jatim Cabang Utama Surabaya Pengaruh Lingkungan Kerja Terhadap Motivasi Kerja Karyawan di Bank Jatim Cabang Utama Surabaya, 2, 1-15.

[17] Rinawati, S. I. (n.d.). Sebagai Variabel Intervening Pada Satuan Kerja Non Vertikal Tertentu ( Snvt) Kementrian Pekerjaan Umum Di Semarang.

[18] Riyanto, S., Sutrisno, A., \& Ali, H. (2017). The Impact of Working Motivation and Working Environment on Employees Performance in Indonesia Stock Exchange. International Review of Management and Marketing, 7(3), 342-348.

[19] Roni, K. A., Moein, A., \& Effendi, N. I. (2018). Determination of Work Motivation and its Implication on Employee Performance Secretariat of Kpu Se-Province Jambi. International Review of Management and Marketing, 8(6), 72-77.

[20] Sajid, K. M. (2019). Management competencies, complexities and performance in 
engineering infrastructure projects of Pakistan. Engineering, Construction and Architectural Management, 26(7), 1321-1347. https://doi.org/10.1108/ECAM-052017-0079

[21] Sudarwati, A. T. dan. (2014). Pengaruh Kompetensi Dan Penghargaan Terhadap Motivasi Kerja Karyawan Pt Kai Di Stasiun Sragen. Jurnal Paradigma Universitas Islam Batik Surakarta, 12(01), 26-40.

[22] Sumantri, D. (2017). The Effect of Individual Characteristics, Competence and Quality of Work Life On Work Motivation, Intention to Leave and Employee Performance Outsoursing Manufacturing Company in East Java Province. Archives of Business Research, 5(5). https://doi.org/10.14738/abr.55.3014

[23] Sutanto, E. M., \& Ratna, A. (2013). Pengaruh Komitmen Organisasional terhadap Kinerja Karyawan Berdasarkan Karakteristik Individual. Journal of Chemical Information and Modeling, 53(9), 1689-1699. https://doi.org/10.1017/CBO9781107415324.004

[24] Suyanto, S. (2018). Competence and discipline on work motivation and the implication on working performance. European Research Studies Journal, 21(1), 570-587.

[25] Usman, J., Sukmayuda, D. N., \& Kurniawati, S. (2019). Job Satisfaction and Employee Performance Shoes Industry in Tangerang Regency Banten Province. International Review of Management and Marketing, 9(1), 98-103.

[26] Waris, A. P. M. dan A. (2015). Effect of Training, Competence and Discipline on Employee Performance in Company (Case Study in PT. Asuransi Bangun Askrida). Procedia - Social and Behavioral Sciences, 211(January), 1240-1251. https://doi.org/10.1016/j.sbspro.2015.11.165

[27] Warouw, C., Sumayku, S. M., \& dan Tumbel, T. M. 2017. (2017). Pengaruh Lingkungan Kerja Terhadap Motivasi Kerja Pada PT BPR Prisma Dana Manado. Jurnal Administrasi Bisnis Unsrat, 53(9), 1689-1699. https://doi.org/10.1017/CBO9781107415324.004

[28] Wibowo. (2017). Manajemen Kinerja (Edisi Keli). Jakarta: PT Raja Grafindo. 